\title{
DELAYING INTEGRATION OF IMMIGRANT LABOR FOR THE PURPOSE OF TAXATION
}

\author{
WOLFRAM F. RICHTER \\ CESIFO WORKING PAPER NO. 802 \\ CATEgORY 1: PUBLIC FinANCE \\ OCTOBER 2002
}
An electronic version of the paper may be downloaded
- from the SSRN website: www.SSRN.com
- from the CESifo website: www.CESifo.de




\title{
DELAYING INTEGRATION OF IMMIGRANT LABOR FOR THE PURPOSE OF TAXATION
}

\begin{abstract}
Delayed Integration ("DI") is a rule for taxing migrants. It requires that immigrants be taxed in the receiving country only after some period of transition. Conversely, emigrants are released from the obligation to pay home taxes only after a certain period. DI is an alternative to the Employment Principle and the Origin Principle. The former governs the international taxation of labor while a close substitute to the latter - the Nationality Principle - is underlying U.S. tax law. The paper studies the potential merits of DI in a setting which allows one to trade off the social cost of tax distortion and the social cost of wasteful government.
\end{abstract}

JEL Classification: H20, H73.

Wolfram F. Richter

University of Dortmund

Department of Economics

44221 Dortmund

Germany

wolfram.richter@uni-dortmund.de 


\section{Introduction}

One of the cornerstones shaping the OECD Model Tax Convention is the Employment Principle ("EP"). A person earning income from employment or personal services pays taxes in the country in which the activity is undertaken even if the person resides in a different country. At least this is the general rule. Deviating specific rules may apply in cases of posted or frontier workers or if services are rendered to governments. This paper questions the practice of relying on EP in international taxation and it offers a discussion of the alternatives.

The specific feature of EP is that it provides strong incentives for choosing employment where taxes are low. This has advantageous as well as disadvantageous implications. The orthodox theory of international taxation focuses on the latter. Its advocates, standing in the tradition of welfare economics, stress the efficiency cost of non-harmonized taxation. Labor will be inefficiently allocated if earned income is taxed differently at different places. The orthodox approach to taxation is closely connected to the view of governments acting as benevolent maximizers of social welfare. This approach has been criticized by those economists viewing tax authorities more in the role of a Leviathan pursuing its own objectives and wasting tax revenue. The most prominent reference is Brennan and Buchanan (1980). These economists stress the merits of competition among institutions, in general, and among countries, in particular. According to Brennan and Buchanan (1980, p. 186), tax competition among separate jurisdictions is an objective to be sought in its own right. 
Hence, the conclusion to be drawn from the literature ${ }^{1}$ is that tax competition produces costs and benefits. The costs come from tax distortion and increase if individuals are allowed to avoid paying taxes by switching their place of employment. The benefits result from the efficiency enhancing effect of competition. Competition among tax authorities is a mechanism constraining the waste of tax revenue.

There have been attempts by Edwards and Keen (1996) and Rauscher (2000) to model the trade off between the costs and benefits of tax competition and to work out an optimal solution. The attempts must be considered to be disappointing for all those expecting clear-cut results. There is obviously no general rule saying that the costs of tax competition exceed the benefits or vice versa. As one may well expect, it all depends on behavioral parameters. A typical result is that of Edwards and Keen (1996) derived for a setting in which mobile capital is taxed by a small jurisdiction. Tax competition is costly on balance if the elasticity of the mobile tax base exceeds the Leviathan's marginal propensity to waste tax revenue.

With such a result in mind, it is not clear how one should assess EP as one of the cornerstones of the OECD Model Tax Convention. On the one hand, EP must be viewed as the cause of distortions in taxpayers' locational choices. On the other hand, it enables effective tax competition which promises to tame Leviathan governments. Assessing EP is, therefore, not easy. However, it is not least a question of alternatives. A conceivable alternative is suggested by the practice of the United States not to release its citizens from the obligation to pay home taxes while residing abroad. This is the so-called Nationality Principle. U.S. citizens cannot escape home taxes just by

\footnotetext{
${ }^{1}$ For a recent survey see Oates (2002).
} 
moving abroad. The United States only grant its citizens relief from double taxation. Foreign paid income tax is credited - up to certain limitations - against U.S. tax. The problem with the Nationality Principle is that it is politically not acceptable for Europe. It deeply conflicts with the widely agreed objective of overcoming nationalistic tendencies in international relations. In this very spirit, Article 12 of the EU Treaty forbids the Member States of the European Union to discriminate on grounds of nationality. On the other hand, one need not rely on the Nationality Principle explicitly if one would only like to reap the economic benefits which its implementation promises. From an economics' point of view, there is an almost perfect substitute for the Nationality Principle and it has been advocated under the name of the Home-Country Principle by Sinn in various writings. See a.o. Sinn (1994). This principle is also called the Origin Principle ("OP") and it is this terminology which will be used in the following discussion. Sinn pleaded for its adoption with a particular conception of the welfare state. The primary function of the welfare state would be to provide insurance against income risks and uncertain life careers. What appears ex post to be redistribution is insurance from an ex ante point of view. Whenever individuals are allowed to switch insurance freely ex post, there is the risk of adverse selection. This would weaken the ex ante insurance function which the welfare state is expected to provide. According to Sinn, individuals should therefore only be free to choose between competing redistributive systems ex ante when young and ignorant about career perspectives. The redistributive system they choose then defines the country of origin, or the home country. Switching the country of origin ex post should not be allowed. Sinn rejects EP not only because it distorts migration decisions, but, above all, because it undermines the insurance function of the welfare state. 
Still, the case for OP is not that clear. The reason is the same one that causes reluctance to denounce any tax competition. By minimizing the cost of tax distortion, OP only eases the wasting of tax revenue. Taxpayers become exploitable when they cannot avoid home taxes by emigrating. On the other hand, OP is not the only conceivable alternative to EP. In a sense which still has to be made precise, it is just an extreme alternative and there are less extreme ones which promise reduced costs of tax distortion without fully unleashing the Leviathan. Such a solution has recently been proposed by the Council of Economic Advisors to the German Ministry of Finance (2001) for the task of coordinating Europe's decentralized policies in the field of social security. The Council coined the name of Delayed Integration ("DI"). DI means that migrants remain assigned to their country of origin for fiscal purposes for an agreed period of time after emigrating. Only after this period has elapsed does the country of immigration take over the fiscal competence for these particular persons. The concept is not completely novel. Vestiges of it can be found here and there in social policy legislation and foreign tax codes. An example of the former was California's practice of limiting new residents for the duration of one year to the benefits they would have received in the State of their prior residence. ${ }^{2}$ An example for the latter is Germany's practice of keeping emigrants subjected to German taxation on that part of their income that originates in Germany for a period of five years if they move to a low income jurisdiction. A similar rule applies to U.S. expatriates. Emigrants form the United States remain subjected to U.S. tax law for a period of ten years after losing U.S. citizenship. The systematic application of DI in international policy coordination, however, has only recently attracted particular attention (Sakslin, 1997; Weichen

\footnotetext{
${ }^{2}$ The durational residency requirements of California have been found unconstitutional by the Supreme Court.
} 
rieder, 2000; Richter, 2002a and 2002b). What is still lacking is a thorough analysis of the potential merits of DI. It must be considered an open question of why and when one should give preference to DI when EP or OP are the alternatives. This is where the present paper ties in.

This paper is structured as follows. Section 2 develops the simple model of a small open economy. The model allows one to separate the social costs of tax distortion and of wasteful government in the succeeding sections. Section 3 looks at a country of immigration and Section 4 at one of emigration. It is shown in both cases that the policy of implementing DI dominates OP whenever the Leviathan's propensity to waste tax revenue is sufficiently strong. No such clear-cut result will, however, be derived for the comparison of DI and EP. In any case, the Leviathan turns out to be less powerful if it is forced to target the political support of natives and not that of taxpayers. Furthermore, the Leviathan enjoys more power under conditions of immigration. Section 5 summarizes, makes qualifications and draws some conclusions.

\section{A simple model}

Consider a small open economy the production $F(L)$ of which only varies with mobile labor $L$. Marginal productivity is positive and decreasing, $F^{\prime}>0>F^{\prime \prime}$. Primes indicate the derivatives of functions throughout. A decreasing marginal product can be justified by the existence of a hidden fixed factor. In this paper, the fixed factor is 
interpreted as immobile labor. The implicit assumption is that mobility is an innate ability.

Production output is an all-purpose private good serving as numéraire. There is an additional good $G$ which is interpreted as a public good and which is consumed by immobile labor only. The utility derived is $V(G)$ with marginal increments which are positive and decreasing, $V^{\prime}>0>V^{\prime \prime}$. The public good is provided by a Leviathan government. The cost of provision is $1+c$ per unit. The parameter $c>0$ is a measure of the Leviathan's marginal propensity to waste tax revenue. From a positive point of view, $C=c G$ is some overhead cost of provision. The assumption, however, is that it is not an unavoidable cost. It is expenditure benefiting the Leviathan only. For mobile and immobile labor, it is pure waste preventing the public sector from producing at its efficiency frontier. For the sake of simplicity, such waste is assumed to be strictly proportional in $G$. This represents a slight difference to Edwards and Keen (1996) and Rauscher (2000), who model the structure of public expenditures as an endogenous decision. Proportionality of waste, though, is not the only simplification adopted for the following analysis. The standard framework of the literature is further simplified with respect to the Leviathan's objective function, which will be additive between its own consumption, $C$, and the utilitarian welfare of labor, $U$. The idea is that the Leviathan has to trade off its own consumption against the public support for its administration and that both objectives are perfectly substitutable. Hence, the Leviathan maximizes $C+U$. Additionally, income effects of the private demand for the public good are ruled out by assuming $U(G, X)=V(G)+X$ to be quasi-linear in $G$ and aggregate private consumption $X$. The latter equals labor income after tax. The 
precise definition of $X$ requires some careful thought and can only be given after specifying taxation.

Taxation is chosen to be redistributive in favor of immobile labor. Such a distributive bias is justified by the robust empirical observation that mobility is skill driven and that skill and income are positively correlated. This makes non-skilled immobile labor the natural target of distributive policy. Redistribution is designed in the most simple way. It is assumed that immobile labor does not have to pay non-zero taxes although it is the only group of individuals deriving utility from the public good $G$. Hence, private consumption of immobile labor equals gross income $F(L)-w L$, with $w$ denoting the cost of mobile labor. Perfect competition in the labor market ensures that wage costs equal marginal productivity, $w=F^{\prime}(L)$. The gross wage paid to mobile labor abroad is $w^{*}$. As the focus is on a small country, $w^{*}$ is treated as an exogenous parameter. In what follows, an asterix ${ }^{*}$ indicates a foreign parameter.

As already mentioned, positive taxes are paid by mobile labor only. In order to specify the exact amount of taxes, the home country's perspective is adopted. If mobile labor originating from home is employed at home, it pays taxes $t$ per unit. Migrants are taxed differently, however. They are taxed according to a formula which is flexible enough to cover some interesting cases. Let us focus on labor immigrating to the home country. As immigrants they pay taxes $\left(1-\delta_{i}\right) t$ to the home country. $\delta_{i}$ can be interpreted as a rebate granted by the home country to immigrants on their tax liability. The way the rebate has been introduced into the political discussion by Council of Economic Advisors (2001), however, suggests interpreting $\delta_{i}$ not as an explicit rebate but as an implicit rebate granted in the form of a temporary delay in tax liability. 
Although the present model is a static one, such a dynamic interpretation of $\delta_{i}$ is straightforward. For instance, if $\delta_{i}$ equals zero, there is no delay granted and immigrants are liable to pay full taxes to the home country from the very moment they get employed in the home country. This amounts to taxing according to EP as suggested by the OECD Model Tax Convention. If $\delta_{i}$ is chosen to equal one, immigrants do not have to pay taxes to the home country. For tax purposes they are treated as non-existent. It is as if their integration were delayed to infinity. In what follows, the term of Delayed Integration ("DI") will, however, be used only if $\delta_{i}$ is strictly between zero and one.

Immigrants to the home country are emigrants from abroad. The logic of DI requires them to remain subjected to tax liability abroad for some time. Let $\delta_{e}^{*} t^{*}$ be the tax emigrants from abroad pay abroad. Hence, when migrating to the home country their overall tax liability amounts to $\left(1-\delta_{i}\right) t+\delta_{e}^{*} t^{*}$. Interpret $\delta_{e}^{*}$ as the delay chosen abroad for releasing emigrants from the obligation to pay taxes abroad. If $\delta_{e}^{*}$ equals one, the emigrant is never released from paying taxes abroad, as suggested by OP. If $\delta_{e}^{*}$ equals zero, the emigrant stops paying taxes abroad at the very moment she emigrates. A priori, one cannot rule out the possibility that a country finds it optimal to treat immigrants and emigrants non-symmetrically. As to the home country, this would mean that the delay in integration, $\delta_{i}$, comes to differ from the delay in releasing emigrants from the obligation to pay home taxes, $\delta_{e}$. Non-harmonized parameters of delay in the countries of immigration and emigration would, however, result either in double taxation or in a temporary exemption from taxation. Both cases are 
problematic. An obvious objective of international tax coordination should therefore be the equalization of delays, $\delta_{i}=\delta_{e}=\delta_{i}^{*}=\delta_{e}^{*} \equiv \delta$. In this special case, the tax liability of migrants shows up as the convex combination of home and foreign tax rates. This property allows one to interpret DI as a convex combination of EP and OP and the latter principles as polar.

Mobile labor is assumed not to consume the public good $G$. Hence, it makes sense to model the migration decision of mobile labor by pure net-wage arbitrage. If migration is from abroad to home, arbitrage is between $w^{*}-t^{*}$ and $w-\left(1-\delta_{i}\right) t-\delta_{e}^{*} t^{*}$. An equilibrium is reached if $w-\left(1-\delta_{i}\right) t=w^{*}-\left(1-\delta_{e}^{*}\right) t^{*}$. Symmetrically, if mobile labor emigrates from the home country, arbitrage is between $w-t$ and $w^{*}-\left(1-\delta_{i}^{*}\right) t^{*}-\delta_{e} t . \quad$ In this case, an equilibrium is reached if $w-\left(1-\delta_{e} t\right)=w^{*}-\left(1-\delta_{i}^{*}\right) t^{*}$. Both cases are covered by the joint equilibrium condition

$$
F^{\prime}(L)-\left(1-\delta_{\bullet}\right) t=w^{*}-\left(1-\delta_{\circ}^{*}\right) t^{*}
$$

with appropriate choices of $\operatorname{dots}(\bullet, \circ)=(i, e)$ or $(e, i)$, respectively.

Tax revenue is used to finance government expenditure. In stating the condition of budget balance, one has to differentiate again between immigration and emigration. Let $\bar{L}$ denote the initial endowment of mobile labor in the home country. For the sake of brevity, it is said to be mobile native labor. Immigration to the home country prevails if mobile labor employed exceeds native labor, $\bar{L}<L$, and if mobile native labor has no incentive to emigrate. The latter is ensured if $\left(1_{e}\right)$ holds with $" \geq "$ 
substituted for "=". Given immigration to the home country, the government budget is balanced if

$$
t\left[\bar{L}+\left(1-\delta_{i}\right)(L-\bar{L})\right]=(1+c) G .
$$

Mutatis mutandis, emigration is characterized by $\bar{L}>L$, by a condition of balanced budget

$$
t\left[L+\delta_{e}(\bar{L}-L)\right]=(1+c) G,
$$

and by some $\left(1_{i}\right)$ with $" \leq$ " substituted for "=".

The description of the model is finished by defining the home country's aggregate private consumption. In doing so, it is important to differentiate between two conceptions. One is taxpayers' consumption and the other is natives' consumption. In order to derive private consumption, one has to add up the incomes after tax that accrue to the various suppliers of labor. In the case of taxpayers' consumption, this is income of immobile labor, $F(L)-F^{\prime}(L) L$, income of mobile natives, $\left(F^{\prime}(L)-t\right) \bar{L}$, and income accruing to immigrants, though only to the amount that they are taxpayers in the home country, $\left(F^{\prime}-t\right)\left(1-\delta_{i}\right)(L-\bar{L})$. Adding up these terms and making use of $\left(2_{i}\right)$ yields

$$
X_{i}^{T}=F(L)-\delta_{i}(L-\bar{L}) F^{\prime}(L)-(1+c) G .
$$

By similar reasoning, taxpayers' private consumption adds up to

$$
X_{e}^{T}=F(L)+\delta_{e}(\bar{L}-L) w^{*}-(1+c) G
$$

if labor is emigrating from home. Note that immobile labor income is subsumed under taxpayers' income although it is not liable to pay positive tax. This makes sense as 
immobile labor is affected by budget policy via public expenditures and it is only for the sake of simplicity that it is assumed to pay zero tax.

The competing conception is natives' consumption. It is obtained by adding up the incomes after tax accruing to natives. In the case of immigration, this is income earned by immobile labor, $F(L)-F^{\prime}(L) L$, and income earned by mobile natives, $\left(F^{\prime}(L)-t\right) \bar{L}$. Summing yields

$$
X_{i}^{N}=F(L)-(L-\bar{L}) F^{\prime}(L)-t \bar{L} .
$$

Mutatis mutandis, natives' consumption is

$$
X_{e}^{N}=F(L)+(\bar{L}-L)\left(w^{*}-\left(1-\delta_{i}^{*}\right) t^{*}\right)-(1+c) G
$$

in the case of emigration. Below, natives will be the reference for welfare comparisons. Natives are, however, not necessarily the individuals whose political support the Leviathan can be assumed to seek. Neither are taxpayers. If anything, a Leviathan government will seek the support of voters and it is the question in the modeling whether voters should be assumed to be natives or taxpayers. Arguments can be found for both.

Internationally, the common rule is that voting rights are tied to citizenship and not to the status of paying taxes. On the other hand, citizens of the European Union are granted the right to vote and to stand as a candidate in municipal elections and elections to the European Parliament in the Member State in which these citizens reside. This proves that the Union is well on its way to separating voting rights from national citizenship and to linking them to residence, which for present purposes can be interpreted as a good proxy for the liability to pay income tax. From a constitutional 
point of view, denying immigrants the right to vote is an institutional constraint requiring justification in its own right. Without such a constraint, one would expect individuals to vote where they pay taxes and/or consume local public goods. Hence, it is not really clear whose support a Leviathan government should be assumed to seek if such an assumption is to be well justified in positive analysis. There are good reasons for equating the electorate with natives and there are equally good reasons for equating the electorate with taxpayers. Therefore, both alternatives will be discussed below. By doing so, some light is shed on the effect that constraining voting rights to natives has on Leviathan behavior. ${ }^{3}$

\section{Optimal delay in the case of immigration}

Consider the task of fixing rules of international taxation in some kind of constitutional assembly. An answer is then required to the question of which delay natives should choose for taxing migrant labor anticipating that future governments have a propensity to waste tax revenue. This is a normative question with a flavor of public choice. It is best stated in terms of principal and agent. The native population serves as the principal and the Leviathan government as the agent. Such a conception suggests starting the analysis by first solving the agent's problem. For this purpose, we differentiate between immigration and emigration and we start by analyzing the former.

\footnotetext{
${ }^{3}$ Michel et al. (1998) study the effect that some delayed granting of citizenship has on distributive policy. In contrast to the model of the present paper, they assume low-skilled labor to be mobile. See also Razin and Sadka (2001, Sect. 6).
} 


\subsection{Taxpayers' support}

Assuming first that the Leviathan government seeks the support of taxpayers, the government can be assumed to maximize $c G+V(G)+X_{i}^{T}$ in $G, t, L$ subject to $\bar{L} \leq L$, $\left(1_{i}\right),\left(2_{i}\right)$, and $\left(3_{i}\right)$. Restrict consideration to interior solutions, $\bar{L}<L$, and assume that in the optimum, home labor cannot gain from emigrating, $F^{\prime}(L)-\left(1-\delta_{e}\right) t>w^{*}-\left(1-\delta_{i}^{*}\right) t^{*}$. Then solve for the resulting standard Lagrangean optimization parameterized by $\delta_{i}$. It is straightforward to show that optimal government choices of $G, t, L$ solve $\left(1_{i}\right),\left(2_{i}\right)$, and

$$
\left(1-V^{\prime}\right) G F^{\prime \prime}=\left(1-\delta_{i}\right)^{2} t\left(F^{\prime}+t \frac{V^{\prime}-1}{1+c}\right)-\delta_{i}\left(1-\delta_{i}\right) t(L-\bar{L}) F^{\prime \prime}
$$

A first noteworthy result is that $\delta_{i}=1$ implies $V^{\prime}=1$. The latter condition characterizes efficient consumption of the public good while $\delta_{i}=1$ stands for a regime in which immigrants are not taxed as required by OP. Efficient consumption of public goods may not be what one would expect to result from Leviathan activity. Still, it makes sense in the present model. The Leviathan has no reason to deviate from the first-best level of $G$ because from its perspective, there is no efficiency cost of taxation. Immigrants are not taxed anyway and the tax on mobile natives is infra-marginal. Quasi-linearity of the utilitarian welfare function ensures that Leviathan activity has some private income effect only. The level of taxation chosen by the Leviathan is too high, but the level of public good consumption is at its first best.

Unfortunately, things are more complicated if $\delta_{i} \neq 1$. Differentiating $\left(1_{i}\right),\left(2_{i}\right)$, and (5) implicitly and solving for $G^{\prime}, L^{\prime}$ and $t^{\prime}$ as functions of $\delta_{i}$ produces some complex 
expressions, the interpretation of which is anything but straightforward. However, letting $\delta_{i}$ tend to one yields the following limit expressions:

$$
\begin{aligned}
& G^{\prime}=-t(L-\bar{L}) / G V^{\prime \prime}>0, \\
& L^{\prime}=-t / F^{\prime \prime}>0 . \\
& t^{\prime}=t(L-\bar{L})\left(1-\frac{1+c}{G V^{\prime \prime}}\right) / \bar{L}>0 .
\end{aligned}
$$

It is suggestive to address the case of some $\delta_{i}$ close to one as one of "large delay". This allows one to interpret (6) - (8) as follows. If the chosen delay is already large, increasing it even more and marginally will have the following effects. The provision of the public good $G$ will increase and reach the level of first-best consumption in the limit. Immigration, $L-\bar{L}$, will equally increase till it reaches the nationally efficient level characterized by $F^{\prime}(L)=w^{*}-\left(1-\delta_{e}^{*}\right) t$. Finally, the tax $t$ increases till it reaches a local maximum at $\delta_{i}=1$. Note that the Leviathan's propensity to waste tax revenue, $c$, only impacts the change in $t$. The more wasteful the Leviathan is, the more taxation will increase along with $\delta_{i} \rightarrow 1$. It is also interesting to note that $G^{\prime}$ and $t^{\prime}$ are both proportional in $L-\bar{L}$. The Leviathan's power to exploit taxpayers obviously benefits from immigration. All these effects would hardly be so clear-cut if the Leviathan's objective function were not additive in its own consumption and taxpayers' welfare and if the latter would fail to be quasi-linear. However, the identified effects are all very plausible.

At the constitutional level, the problem is to choose the parameter of delay $\delta_{i}$ given the behavioral reactions as defined implicitly by $\left(1_{i}\right),\left(2_{i}\right)$, and $(5)$. One would like to 
answer the following two questions. First, is there good reason to choose $\delta_{i} \in(0,1)$ and to institute DI? Second, if not, should one give preference to $\delta_{i}=0$ (EP) or better to $\delta_{i}=1(\mathrm{OP})$ ? Unfortunately, clear-cut results are out of reach and this has to be explained.

A priori, one might speculate that aggregate welfare of natives,

$$
W\left(\delta_{i}\right)=V\left(G\left(\delta_{i}\right)\right)+X_{i}^{N}\left(G\left(\delta_{i}\right), t\left(\delta_{i}\right), L\left(\delta_{i}\right)\right),
$$

is maximized by some interior $\delta_{i} \in(0,1)$. The necessary condition for this to hold is

$$
\begin{aligned}
0 & \stackrel{!}{=} W^{\prime}=V^{\prime} G^{\prime}-(L-\bar{L}) F^{\prime \prime} L^{\prime}-t^{\prime} \bar{L} \\
& =\underbrace{\left(V^{\prime}-1\right) G^{\prime}}_{(i)}-\underbrace{(L-\bar{L}) F^{\prime \prime} L^{\prime \prime}}_{(i i)}+\underbrace{(1+c) G^{\prime}-t^{\prime} \bar{L}}_{(i i i)}-\underbrace{c G^{\prime}}_{(i v)} .
\end{aligned}
$$

Hence, there are four effects which have to be balanced on the margin. The first two are marginal changes in "Harberger triangles". (i) is the marginal change of consumption efficiency and (ii) is the marginal change in natives' labor income. (iv) is marginal waste in tax revenue. Finally, (iii) is the marginal change in tax export, i.e., the change in tax revenue paid by non-natives. From the point of view of national welfare, any reduction in tax export adds to the marginal social cost of tax distortion. This extended definition is underlying the following discussion.

The analysis is complicated by the fact that corner solutions cannot be discarded if welfare is to be maximized. Quite to the contrary, if the Leviathan propensity to waste tax revenue vanishes, $c=0$, OP turns out to be optimal. That is, constitutional design should only target tax efficiency in absence of tax waste. The social cost of distortive taxation can be minimized only if immigrants are exempted from home taxes. If the 
Leviathan propensity to waste tax revenue is positive, it is less clear, however, whether OP continues to dominate DI and EP. This may not come as a great surprise given the results of Edwards/Keen (1996) and Rauscher (2000). Still, it is worth stressing. The following example demonstrates that for sufficiently large $c$, preference should be given to EP in a direct comparison with OP.

Example: For $V=4 G^{1 / 2}, F=2 L^{1 / 2}, w^{*}=1 / 4, t^{*}=0, \bar{L}=10$, natives' welfare $W=$ $V+F-(L-\bar{L}) F^{\prime}-t \bar{L}$ obtains values reported in the following table.

\begin{tabular}{|l|l|l|}
\hline \multirow{2}{*}{} & \multicolumn{2}{|l|}{ Natives' welfare in case of } \\
\cline { 2 - 3 } & EP & OP \\
\hline$c=0$ & 8.45 & 10.5 \\
\hline$c=1$ & 7.65 & 6.5 \\
\hline
\end{tabular}

Such a comparison clearly says little about the potential merits of DI. Unfortunately, the comparison of DI with EP is difficult essentially for the same reasons as it is difficult between EP and OP. However, a definite comparison between DI and OP is possible.

Proposition 1: If the Leviathan's propensity, c, to waste tax revenue is positive, eventually subjecting immigrant labor to home taxation, i.e., implementing DI with $\delta_{i}$ large but smaller than one, is a better policy than not subjecting immigrant labor to home taxation and implementing OP. Implementing OP is optimal only for $c=0$. 
For a proof, just insert (6) - (8) into (9) and make use of $V^{\prime}=1$. One then obtains

$$
W^{\prime}=-c G^{\prime}=c t(L-\bar{L}) / G V^{\prime \prime},
$$

which fails to be positive and proves the proposition. Note that the larger $c$ is, the more negative $W^{\prime}$ is and the stronger the case for opting against OP and in favor of DI. The following figure illustrates why welfare comparisons are difficult if values of $\delta_{i}$ that are not close to one are being considered.

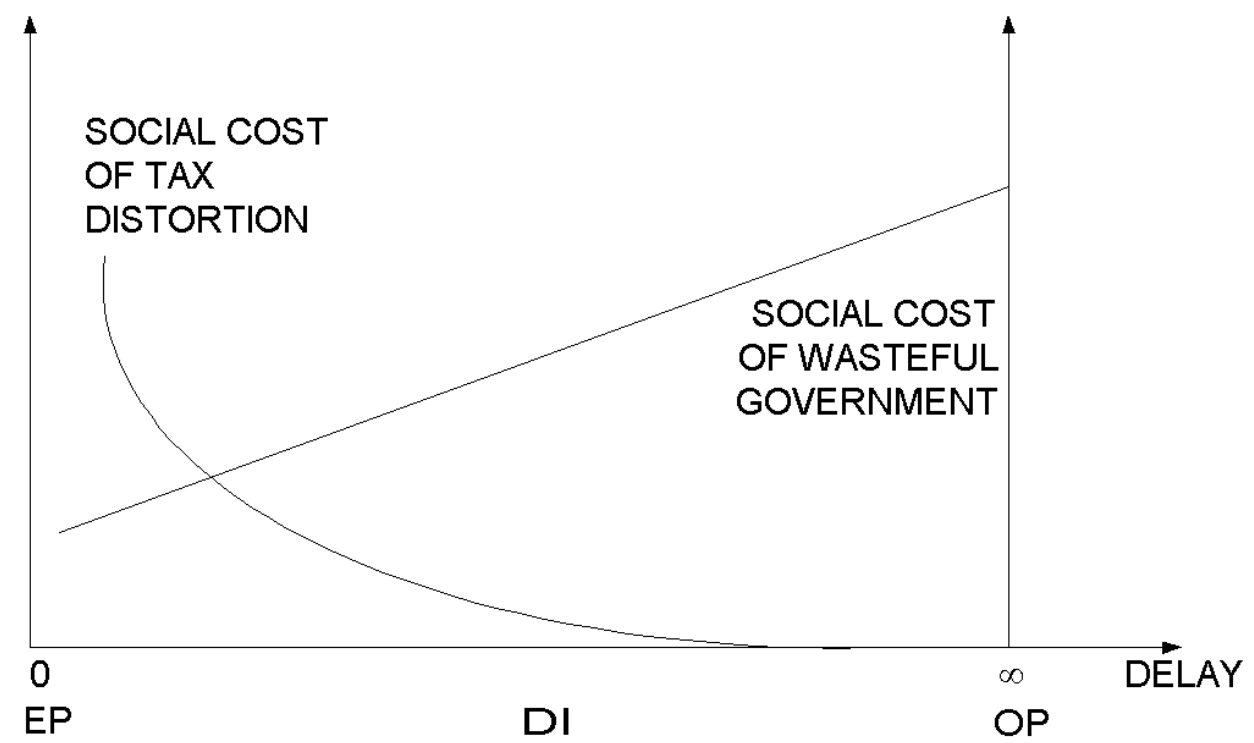

When moving from $\delta_{i}=1$ to some lower value, essentially two effects have to be traded off in a welfare analysis. One is the social cost of tax distortion and the other is the social cost of wasteful government. As the former is an effect of second order in 1$\delta_{i}$ while the latter an effect of first order, no definite welfare comparison is possible between low and large values of $\delta_{i}$ or - expressing the same differently - between strong and weak tax competition. One can only say that for $c>0$, some tax competition $\left(\delta_{i}<1\right)$ dominates the absence of any tax competition $\left(\delta_{i}=1\right)$. 
The case for DI would be stronger if both mobile and immobile labor could be shown to benefit when moving from OP to DI. This is, however, not true. Immobile labor loses, as can easily be demonstrated by means of (6) and (7):

$$
\frac{d}{d \delta_{i}}\left[V+F-L F^{\prime}\right]=V^{\prime} G^{\prime}-L F^{\prime \prime} L^{\prime}>0
$$

There are two reasons why immobile labor loses when introducing tax competition and moving from OP to DI. First, the supply of the public good decreases and, second, immobile wage income shrinks when immigrant mobile labor is taxed. The latter results from the well-known effect that taxes on perfectly mobile factors are shifted backward to the immobile ones and that such shifting is costly in terms of efficiency.

Propostion 2: Immobile labor loses when moving marginally from OP to DI.

\subsection{Natives' support}

In the present setting, policy is evaluated by measuring the welfare of natives. Hence, one may well conjecture that superior results are obtained in terms of welfare if the Leviathan is forced to seek the support of natives and not that of taxpayers. The scope for pursuing some selfish policy is constrained if the Leviathan is forced to include the correct aggregate of labor income in its objective function. Such a conjecture turns out to be correct.

Assuming that the Leviathan seeks the support of natives, it maximizes $c G+V(G)+$ $X_{i}^{N}$ in $G, t, L$ subject to $\bar{L} \leq L,\left(1_{i}\right),\left(2_{i}\right)$, and $\left(4_{i}\right)$. Consideration is restricted again to 
the analysis of interior solutions, $\bar{L}<L, F^{\prime}(L)-\left(1-\delta_{e}\right) t>w^{*}-\left(1-\delta_{i}^{*}\right) t^{*}$. The firstorder conditions of the resulting Lagrangean optimization are $\left(1_{i}\right),\left(2_{i}\right)$, and

$$
\left(1-V^{\prime}\right) G F^{\prime \prime}=\left(1-\delta_{i}\right)^{2} t^{2} \frac{V^{\prime}+c}{1+c} .
$$

Obviously, $\mathrm{V}^{\prime}>1$ for $\delta_{i}<1$. That is, consumption of the public good is below the efficient level except for the case when $\delta_{i}=1$. It is straightforward to demonstrate that $\delta_{i}=1$ is a stationary point of the natives' welfare function. Less clear is whether OP stands for a local maximum or a local minimum of natives' welfare. The following proposition gives the answer. The proof is relegated to the Appendix.

Proposition 3: If the Leviathan propensity, $c$, to waste tax revenue is sufficiently large, it is not optimal to implement OP. It is better to subject immigrant labor to home taxation eventually, i.e., to implement DI with $\delta_{i}$ sufficiently large but smaller than one. Implementing OP is a local optimum only if $c$ takes on small values or $L-\bar{L}$ large ones, respectively.

Proposition 3 is well in line with Proposition 1. Leviathan activity is shown to provide an argument against OP and pro DI. At the same time, Proposition 3 is weaker than Proposition 1. The argument in favor of DI requires some Leviathan propensity to waste tax revenue which is sufficiently large. This accords well with what has been conjectured. It helps to tame the Leviathan if natives alone are allowed to vote and immigrant labor is not. 


\section{Optimal delay in the case of emigration}

The task of designing the optimal delay in releasing emigrant labor from the liability to pay home taxes is analyzed along the same lines developed for the case of immigration. Assuming that the Leviathan seeks the support of taxpayers, it maximizes $c G+V(G)+X_{e}^{T}$ in $G, t, L$ subject to $\bar{L} \geq L,\left(1_{e}\right),\left(2_{e}\right)$, and $\left(3_{e}\right)$. Restricting consideration to interior solutions, $\bar{L}>L, \quad F^{\prime}(L)-\left(1-\delta_{i}\right) t<w^{*}-\left(1-\delta_{e}^{*}\right) t^{*}$, and solving for the resulting Lagrangean optimization yields $\left(1_{e}\right),\left(2_{e}\right)$, and

$$
\left(1-\delta_{e}\right)\left(F^{\prime}-\delta_{e} w^{*}\right)=\frac{1-V^{\prime}}{1+c}\left[t\left(1-\delta_{e}\right)^{2}+\Lambda_{e} F^{\prime \prime}\right]
$$

as first-order conditions. $\Lambda_{e} \equiv L+\delta_{e}(\bar{L}-L)$ is a short form for the mobile tax base. As before, efficient consumption of the public good, $V^{\prime}=1$, is obtained when OP $\left(\delta_{e}=1\right)$ applies. Again, one would like to know how OP compares with DI when $\delta_{e}$ is sufficiently large. A clear-cut result is, however, obtained only for the case in which OP is applied abroad. Assuming $\delta_{i}^{*}=1$, one can show that $\delta_{e}=1$ is a stationary point of the welfare function of the home country's natives. In order to see whether it is a local maximum or minimum, the technique introduced for the proof of Proposition 3 is applied. That is, when differentiating $\left(1_{e}\right),\left(2_{e}\right)$, and (11) implicitly, all terms of second order in $1-\delta_{e}$ are ignored. Note that this technique allows one to ignore the RHS of (11). The LHS is of second order in $1-\delta_{e}$, which follows from inserting $\delta_{i}^{*}=1$ in $\left(1_{e}\right)$ and from noting $F^{\prime}-\delta_{e} w^{*}=\left(1-\delta_{e}\right)\left(w^{*}+t\right)$. When ignoring terms of second order, the derivatives of the endogenous variables turn out to be as follows: 


$$
\begin{aligned}
& L^{\prime} \cong-t \bar{L} / F^{\prime \prime} \Lambda_{e}>0 \\
& G^{\prime} \cong 2\left(1-\delta_{e}\right) \frac{(1+c)\left(w^{*}+t\right)}{V^{\prime \prime} F^{\prime \prime} \Lambda_{e}}>0 \\
& t^{\prime} \cong 2\left(1-\delta_{e}\right) \frac{(1+c)^{2}\left(w^{*}+t\right)}{V^{\prime \prime} F^{\prime \prime} \Lambda_{e}^{2}}+\left(1-\delta_{e}\right) \frac{t^{2}}{F^{\prime \prime} \Lambda_{e}}-\frac{t(\bar{L}-L)}{\Lambda_{e}} .
\end{aligned}
$$

As in the case of immigration, increasing $\delta_{e}$ to large values boosts employment at home and increases the consumption of the public good. The reason is that by increasing $\delta_{e}$, the incentive to avoid paying home taxes by emigrating is reduced. The marginal change in $t$ at $\delta_{e}=1$, however, differs in sign from the immigration case. The RHS of (14) is negative, whereas it is positive in (8). Increasing $\delta_{e}$ to large values thus makes the Leviathan reduce taxes in the country of emigration, whereas it increases taxes in the country of immigration. This must be interpreted as saying that the Leviathan enjoys more strength under conditions of immigration. This interpretation finds further support with the following welfare analysis.

Assuming $\delta_{i}^{*}=1$, differentiating $W=V+X_{e}^{N}=V-(1+c) G+F+(\bar{L}-L) w^{*}$ with respect to $\delta_{e}$, ignoring second-order terms, and plugging in (12) and (13) yields

$$
\begin{aligned}
W^{\prime} & \cong-c G^{\prime}+\left(F^{\prime}-w^{*}\right) L^{\prime}=-c G^{\prime}+\left(1-\delta_{e}\right) t L^{\prime} \\
& =-\frac{1-\delta_{e}}{F^{\prime \prime} \Lambda_{e}}\left[t^{2} \bar{L}+2 c(1+c)\left(w^{*}+t\right) / V^{\prime \prime}\right] .
\end{aligned}
$$

Obviously, the sign of $W^{\prime}$ is ambiguous. The first term of the bracketed expression is positive while the second is negative. The larger $c$ is, the larger the latter term becomes. 
Proposition 4: If the Leviathan's propensity, $c$, to waste tax revenue is sufficiently large, it is not optimal to adopt OP. It increases natives' welfare instead if emigrant labor is eventually released from the liability to pay home taxes. Adopting OP is a local optimum only if $c$ takes on small values.

As marginal welfare $W^{\prime}$ vanishes at $\delta_{e}=1$, there is no efficiency gain to be reaped by a marginal move towards DI. Setting $\delta_{e}$ marginally below one results in pure redistribution from immobile to mobile labor. The marginal gain of mobile native labor can easily be determined by making use of (12) and (14):

$$
-\left.\frac{d}{d \delta_{e}} \bar{L}\left(F^{\prime}-t\right)\right|_{\delta_{e}=1}=t L .
$$

Hence, the marginal gain equals tax revenue collected from mobile labor employed at home.

One may wonder how results change if the Leviathan is assumed to seek the support of natives instead of taxpayers. As it turns out, the changes are only marginal and not upsetting. All that happens is that the variable $w^{*}$ disappears from the formulas (13) (15). As the foreign wage rate $w^{*}$ appears jointly with the factor $1+c$, this has to be interpreted as follows. The effect that selfish government behavior has on marginal changes in $G, t$, and $W$ is dampened if the Leviathan's power is checked by a native electorate. This does not come as much of a surprise given what is already known to hold for the immigration case. The only difference is that the effect of switching from 
a taxpayers' electorate to a natives' electorate turns out to be less pronounced in the emigration case.

\section{Summary and conclusions}

The practice of taxing labor in the country of employment has been questioned in the literature. The reasons are basically twofold. First, the Employment Principle, EP, provides strong incentives for choosing employment where taxes are low. This impedes the efficient allocation of mobile labor and renders non-paretian redistribution in favor of immobile labor costly. Second, by its very nature, EP is not applicable to non-active persons such as the recipients of social assistance. Although this has not been the focus of the present analysis, it is a matter of policy concern in the European Union (Sakslin, 1997; Council of Economic Advisors, 2001). The reason is that free movement is an agreed objective in the Union. The Treaty of Maastricht rules that every citizen of the Union has the right to move and reside freely within the territory of the Member States. At present, this right is effectively limited for non-active persons, in general, and recipients of social assistance, in particular. However, it is safe to assume that the limitations will not stand for ever. Free mobility extended to the recipients of social assistance is an objective for which Europe will have to find a politically viable solution (Richter, 2002b). No matter what this solution looks like, it will conflict with EP.

The policy question is what a good alternative to EP might be. In the literature, the Principles of Origin, OP, and of Delayed Integration, DI, are handled as potential alternatives. OP and DI have the obvious advantage of being directly applicable to 
non-active persons. There is even much sense in requiring the country of origin to support native recipients of social assistance if these persons enjoy their right of free movement. For a more detailed discussion of such a policy, see Richter (2002b). This paper is, however, not one on social assistance and its provision to mobile citizens. The focus is on mobile labor and the question of how OP, DI and EP compare if all individuals are employed. Unfortunately, a clear-cut ranking is only obtained if governments can be assumed to act as benevolent planners. In this case, EP is dominated by DI and the latter by OP in terms of the inflicted social costs of tax distortion. However, OP eliminates fiscal competition. It provides governments with the leeway to abuse their fiscal power because taxpayers cannot threaten to avoid taxation by emigrating. As a result, the incentive for governments to pursue a policy in the interest of their citizens is weak. EP has more of a disciplinary effect on Leviathan governments.

However, no clear-cut results can be derived once due allowance is made to selfish behavior of governments. As this paper demonstrates, it is not clear whether preference should be given to OP or EP in a model which captures the cost of tax distortion and the cost of selfish government. Much depends on the Leviathan's propensity to waste tax revenue. If this propensity is large, OP is dominated by DI with some sufficiently large delay. Unfortunately, no such strong result could be derived with regard to the comparison between OP or DI with EP. There is, however, some weak evidence for the presumption that the case of EP becomes the stronger, the more the Leviathan is inclined to waste tax revenue. 
Besides this, some noteworthy results are obtained. For example, it was shown that a regime of emigration exerts more disciplinary power on a Leviathan government than a regime of immigration. Furthermore, it helps to tame the Leviathan if voting rights are restricted to natives and not granted to immigrant taxpayers.

The relevance of this paper's analysis is not restricted to the taxation of mobile labor. The relevance for social security has already become apparent in passing. Whenever social security does not accord with the Benefit Principle, it either implies implicit taxation or implicit subsidization of migration. In these cases, there are potential costs of distorted locational choices and EP has to be put up for discussion. This paper's relevance, however, goes even further. It extends to other mobile factors such as capital. Clearly terminology would have to be adapted to such an application. For example, taxing labor in the country of employment amounts to taxing capital at source. At least this holds from an analytical and allocational point of view. Similarly, the effects of taxing labor in the country of origin directly compare to those of taxing capital according to the Residence Principle. Even DI finds its counterpart in international taxation of capital. Applying DI to capital amounts to granting some form of tax rebate for inflowing capital. In the case of outflowing capital, DI extends home tax liability for some fixed span of time. In fact, such provisions exist in foreign tax codes, as has been pointed out before.

The Residence Principle is known to ensure a globally efficient allocation of capital. This is often said to be an advantage in comparison to the Source Principle. The argument relies on the production efficiency theorem of Diamond and Mirrless. See a.o. Frenkel, Razin, and Sadka (1991). It is obvious that DI fails to sustain production 
efficiency. However, as argued by Keen and Wildasin (2000), the case for production efficiency is not that strong in an international context. It requires the feasibility of international lump-sum transfers and empirical evidence of this is lacking. This paper chose to focus on national efficiency and to rule out the possibility of international lump-sum transfers.

This is by no means the only assumption in need of discussion. The exogenous division into mobile and immobile labor is critical. In a more general approach, due allowance would have to be made for the fact that mobility is strongly correlated with skill and that the acquisition of skill is an endogenous decision. One must be aware that any policy designed to alleviate the fate of immobile labor may produce severe distortions. Mobility generates efficiency gains, so that any policy targeted at immobility tends to be costly in terms of efficiency. As shown by Wildasin (2000), immobile labor may well benefit indirectly from free mobility if the division into mobile and immobile labor alone is the outcome of market-oriented rational investment in human capital and skills.

One may rightly question the small country assumption which has been the basis for the present analysis. However, one should not expect deep new insights from extending the analysis to large countries. Clearly, terms-of-trade effects would show up. A tax on immigrant labor works like a tariff on imports and that may have a positive income effect of first order. The results obtained in the present paper would need to be qualified appropriately.

Distributive policy has been modeled as being non-paretian. In other words, taxes modeled are a pure burden on mobile labor. Again, such an assumption is debatable. 
An alternative would be to derive distributive policy from mobile taxpayer's altruism (Pauly, 1973). Redistribution would then amount to a public good consumed by mobile taxpayers. The discussion would need to be qualified appropriately. Taxes are well-known not to distort locational choices if they can be rationalized by the Benefit Principle. In fact, taxes need to be levied employment-based if the cost of providing public goods to a marginal migrant is related to employment and if allocational efficiency is to be enhanced. This is just what the application of marginal cost pricing suggests in the case of mobile labor.

An interesting qualification is made by Hange and Wellisch (1998). In a model of benevolent first-best welfare maximization, one would have to endow jurisdictions with the power to balance their public budget without distorting locational choices. The implication is that jurisdictions should have a tax on fixed factors at their disposal. As Hange et al. show, quite the contrary is optimal if governments are assumed to pursue selfish objectives. The idea is that a tax on fixed factors gives the Leviathan leeway to abuse its power of taxation. Interjurisdictional tax competition does not exert any restraining force in this case. The Leviathan should only have access to tax instruments which can be avoided by taxpayers.

Finally, one may rightly question the perfect mobility assumption of which the analysis made such heavy use. Clearly, perfect mobility lacks realism. There are moving costs which have to be offset by migrants against income gains. Costs of mobility are a definite obstacle to the efficient allocation of labor. However, they do not make the present analysis obsolete. Taxes retain there distortive potential on the margin even in the presence of moving costs. 
The propensity to move and the distortions exerted by taxes on locational choices raise a number of empirical questions. They cannot be dealt with adequately at the level of a footnote. For a comprehensive recent survey - albeit in German - see Feld (2000). See also Oates 2002. The bottom line to this literature is that the empirical evidence on the effect that taxes, social benefits, and public goods have on residence choices is somewhat mixed. In the United States, the recipients of social assistance obviously strongly respond to the transfer level. In other countries, notably in Switzerland, social transfers play a less important role. As to taxes, the empirical evidence tends to be reversed. Local taxes have been shown to have strong effects on residence choices in Switzerland. This is especially the case for high income earners, who, incidentally, also react positively to local public expenditures. Low-income earners are not as strongly influenced by taxes in their choice of residence. In the United States, things seem to be different, which could be due to the fact that Sates and local authorities are financed through income taxes only to a minor extent. Hence, from an empirical point of view, it is not fully clear how important the distorting effects of taxes on migration are. Still, economic theory suggests not playing them down but rather thinking carefully about how to assign taxpayers to jurisdictions in a world of increasing mobility.

\section{Appendix}

In order to prove Proposition 3 , it is necessary to solve $\left(1_{i}\right),\left(2_{i}\right),(10)$ for $G^{\prime}, t^{\prime}, L^{\prime}$ as functions of $\delta_{i}$ when this parameter takes on values close to one. For such large values of $\delta_{i}$, terms of second order in $1-\delta_{i}$ are dominated by first-order ones. Hence, it is 
possible to restrict attention to the latter terms. An immediate implication is that the left hand side of (10) can be ignored when computing the Jacobian of $\left(1_{i}\right),\left(2_{i}\right),(10)$. It is an expression which quadratically tends to zero for $\delta_{i} \rightarrow 1$. When ignoring terms of second order, implicit differentiation of $\left(1_{i}\right),\left(2_{i}\right),(10)$ yields

$$
\left[\begin{array}{ccc}
0 & -\left(1-\delta_{i}\right) & F^{\prime \prime} \\
-(1+c) & \Lambda_{i} & t\left(1-\delta_{i}\right) \\
-G V^{\prime \prime} F^{\prime \prime} & 0 & 0
\end{array}\right]\left[\begin{array}{c}
G^{\prime} \\
t^{\prime} \\
L^{\prime}
\end{array}\right] \cong\left[\begin{array}{c}
-t \\
t(L-\bar{L}) \\
-2 t^{2}\left(1-\delta_{i}\right) \frac{V^{\prime}+c}{1+c}
\end{array}\right]
$$

with $\Lambda_{i}=\bar{L}+\left(1-\delta_{i}\right)(L-\bar{L})$. As a result,

$$
L^{\prime} \cong-t / F^{\prime \prime}>0,
$$

and for $\delta_{i}<1$,

$$
\begin{aligned}
& G^{\prime} \cong 2 \frac{1-V^{\prime}}{\left(1-\delta_{i}\right) V^{\prime \prime}}>0 \\
& t^{\prime} \cong \frac{t}{F^{\prime \prime} \Lambda}\left[(L-\bar{L}) F^{\prime \prime}+t\left(1-\delta_{i}\right)-2 t \frac{\left(1-\delta_{i}\right)\left(c+V^{\prime}\right)}{G V^{\prime \prime}}\right] .
\end{aligned}
$$

Plugging such expressions into the marginal welfare function $W^{\prime}$ yields

$$
\begin{aligned}
W^{\prime} & =V^{\prime} G^{\prime}-(L-\bar{L}) F^{\prime \prime} L^{\prime}-\bar{L} t^{\prime} \\
& \cong 2 \frac{1-V^{\prime}}{\left(1-\delta_{i}\right) V^{\prime \prime}}+\left(1-\delta_{i}\right) \frac{L-\bar{L}}{\Lambda}+\frac{\left(1-\delta_{i}\right) t^{2}}{F^{\prime \prime} \Lambda}\left[1-2 \frac{c+V^{\prime}}{G V^{\prime \prime}}\right] .
\end{aligned}
$$

Hence,

$$
\left.\frac{W^{\prime}}{1-\delta_{i}}\right|_{\delta_{i} \rightarrow 1}=2 t^{2} \frac{V^{\prime}}{G V^{\prime \prime}} \frac{1}{F^{\prime \prime}}+\frac{L-\bar{L}}{\bar{L}}+\frac{t^{2}}{F^{\prime \prime} \bar{L}}\left[1-2 \frac{c+1}{G V^{\prime \prime}}\right] .
$$


The first two terms on the RHS are positive while the third is negative. Proposition 3 is obtained after signing the RHS.

\section{References}

Brennan, G. and J.M. Buchanan, 1980, The Power to Tax: Analytical Foundations of a Fiscal Constitution, Cambridge/Mass.

Council of Economic Advisors to the Ministry of Finance, 2001, Freizügigkeit und soziale Sicherung in Europa (Free Movement and Social Security in Europe), Schriftenreihe des BMF, Heft 69, Stollfuß Verlag, Bonn.

Diamond, P.A. and J.A. Mirrless, 1971, Optimal Taxation and Public Production, American Economic Review 111, 8-27 and 261-278.

Edwards, J. and M. Keen, 1996, Tax Competition and Leviathan, European Economic Review 40, 113-134.

Feld, L.P. 2000, Steuerwettbewerb und seine Auswirkungen auf Allokation und Distribution (Tax Competition and its Effects on Allocation and Distribution), Mohr Siebeck, Tübingen.

Frenkel, J.A., A. Razin, and E. Sadka, 1991, International Taxation in an Integrated World, MIT Press, Cambridge, Mass.

Hange, U., and D. Wellisch, 1998, The Benefit of Fiscal Decentralization, FinanzArchiv 55, 315-327.

Keen, M., and D.E. Wildasin, 2000, Pareto Efficiency in International Taxation, CESifo Working Paper No. 371.

Michel, Ph., P. Pestieau and J.-P. Vidal, 1998, Labor Migration and Redistribution with Alternative Assimilation Policies: The Small Economy Case, Regional Science and Urban Economics 28, 363-377.

Oates, W.E., 2002, Fiscal and Regulatory Competition: Theory and Evidence, forthcoming in: Perspektiven der Wirtschaftspolitik.

Pauly, M.V., 1973, Income Redistribution as a Local Public Good, Journal of Public Economics 2, 35-58.

Rauscher, M., 2000, Interjurisdictional Competition and Public-Sector Prodigality: The Triumph of the Market over the State? FinanzArchiv 57, 89-105.

Razin, A., and E. Sadka, 2001, Labor, Capital, and Finance, Cambridge University Press, Cambridge, UK 
Richter, W.F., 2002, Delayed Integration of Mobile Labor: A Principle for Coordinating Taxation, Social Security, and Social Assistance, forthcoming

Richter, W.F., 2002, Social Security and Taxation of Labour Subject to Subsidiarity and Freedom of Movement, forthcoming in: Swedish Economic Policy Review.

Sakslin, M., 1997, Can the Principles of the Nordic Conventions on Social Protection Contribute to the Modernisation and Simplification of Regulation (EEC) No. 1408/71?, in: 25 Years of Regulation (EEC) No. 1408/71 on Social Security for Migrant Workers, Swedish National Social Insurance Board, ed., Stockholm, 199-227.

Sinn, H.-W., 1994, How Much Europe? Subsidiarity, Centralization and Fiscal Competition, Scottish Journal of Political Economy 41, 85-107.

Weichenrieder, A., 2000, A Simple Rule for Taxing the Mobile Rich, mimeo, University of Munich.

Wildasin, D.E., 2000, Labor-Market Integration, Investment in Risky Human Capital, and Fiscal Competition, American Economic Review 90, 73-95. 


\section{CESifo Working Paper Series}

(for full list see www.cesifo.de)

735 Sandro Brusco and Fausto Panunzi, Reallocation of Corporate Resources and Managerial Incentives in Internal Capital Markets, May 2002

736 Stefan Napel and Mika Widgrén, Strategic Power Revisited, May 2002

737 Martin W. Cripps, Godfrey Keller, and Sven Rady, Strategic Experimentation: The Case of Poisson Bandits, May 2002

738 Pierre André Chiappori and Bernard Salanié, Testing Contract Theory: A Survey of Some Recent Work, June 2002

739 Robert J. Gary-Bobo and Sophie Larribeau, A Structural Econometric Model of Price Discrimination in the Mortgage Lending Industry, June 2002

740 Laurent Linnemer, When Backward Integration by a Dominant Firm Improves Welfare, June 2002

741 Gebhard Kirchgässner and Friedrich Schneider, On the Political Economy of Environmental Policy, June 2002

742 Christian Keuschnigg and Soren Bo Nielsen, Start-ups, Venture Capitalits, and the Capital Gains Tax, June 2002

743 Robert Fenge, Silke Uebelmesser, and Martin Werding, Second-best Properties of Implicit Social Security Taxes: Theory and Evidence, June 2002

744 Wendell Fleming and Jerome Stein, Stochastic Optimal Control, International Finance and Debt, June 2002

745 Gene M. Grossman, The Distribution of Talent and the Pattern and Consequences of International Trade, June 2002

746 Oleksiy Ivaschenko, Growth and Inequality: Evidence from Transitional Economies, June 2002

747 Burkhard Heer, Should Unemployment Benefits be Related to Previous Earnings?, July 2002

748 Bas van Aarle, Giovanni Di Bartolomeo, Jacob Engwerda, and Joseph Plasmans, Staying Together or Breaking Apart: Policy-makers' Endogenous Coalitions Formation in the European Economic and Monetary Union, July 2002

749 Hans Gersbach, Democratic Mechanisms: Double Majority Rules and Flexible Agenda Costs, July 2002

750 Bruno S. Frey and Stephan Meier, Pro-Social Behavior, Reciprocity or Both?, July 2002 
751 Jonas Agell and Helge Bennmarker, Wage Policy and Endogenous Wage Rigidity: A Representative View From the Inside, July 2002

752 Edward Castronova, On Virtual Economies, July 2002

753 Rebecca M. Blank, U.S. Welfare Reform: What's Relevant for Europe?, July 2002

754 Ruslan Lukach and Joseph Plasmans, Measuring Knowledge Spillovers Using Patent Citations: Evidence from the Belgian Firm's Data, July 2002

755 Aaron Tornell and Frank Westermann, Boom-Bust Cycles in Middle Income Countries: Facts and Explanation, July 2002

756 Jan K. Brueckner, Internalization of Airport Congestion: A Network Analysis, July 2002

757 Lawrence M. Kahn, The Impact of Wage-Setting Institutions on the Incidence of Public Employment in the OECD: 1960-98, July 2002

758 Sijbren Cnossen, Tax Policy in the European Union, August 2002

759 Chandima Mendis, External Shocks and Banking Crises in Developing Countries: Does the Exchange Rate Regime Matter?, August 2002

760 Bruno S. Frey and Lars P. Feld, Deterrence and Morale in Taxation: An Empirical Analysis, August 2002

761 Lars Calmfors and Åsa Johansson, Nominal Wage Flexibility, Wage Indexation and Monetary Union, August 2002

762 Alexander R. W. Robson and Stergios Skaperdas, Costly Enforcement of Property Rights and the Coase Theorem, August 2002

763 Horst Raff, Preferential Trade Agreements and Tax Competition for Foreign Direct Investment, August 2002

764 Alex Cukierman and V. Anton Muscatelli, Do Central Banks have Precautionary Demands for Expansions and for Price Stability? - Theory and Evidence, August 2002

765 Giovanni Peri, Knowledge Flows and Knowledge Externalities, August 2002

766 Daniel Friedman and Nirvikar Singh, Equilibrium Vengeance, August 2002

767 Sam Bucovetsky and Michael Smart, The Efficiency Consequences of Local Revenue Equalization: Tax Competition and Tax Distortions, August 2002

768 Tapio Palokangas, International Labour Market Regulation and Economic Growth with Creative Destruction, August 2002

769 Rudi Dornbusch, The New International Architecture, September 2002 
770 Hans-Werner Sinn, Weber's Law and the Biological Evolution of Risk Preferences: The Selective Dominance of the Logarithmic Utility Function, September 2002

771 Thomas Mayer, The Macroeconomic Loss Function: A Critical Note, September 2002

772 Seppo Honkapohja and Kaushik Mitra, Learning Stability in Economies with Heterogenous Agents, September 2002

773 David Laidler, Inflation Targets Versus International Monetary Integration - A Canadian Perspective, September 2002

774 Morten I. Lau, Panu Poutvaara, and Andreas Wagener, The Dynamic Cost of the Draft, September 2002

775 Steven Brakman, Harry Garretsen, and Charles van Marrewijk, Locational Competition and Agglomeration: The Role of Government Spending, September 2002

776 Anke S. Kessler and Christoph Lülfesmann, The Theory of Human Capital Revisited: On the Interaction of General and Specific Investments, September 2002

777 Kjell Erik Lommerud, Frode Meland and Lars Sørgard, Unionized Oligopoly, Trade Liberalization and Location Choice, September 2002

778 Antonio Merlo and François Ortalo-Magné, Bargaining over Residential Real Estate: Evidence from England, September 2002

779 Yu-Fu Chen and Michael Funke, Exchange Rate Uncertainty and Labour Market Adjustment under Fixed and Flexible Exchange Rates, September 2002

780 Michael S. Michael, International Migration, Income Taxes and Transfers: A Welfare Analysis, September 2002

781 Clemens Fuest and Alfons Weichenrieder, Tax Competition and Profit Shifting: On the Relationship between Personal and Corporate Tax Rates, October 2002

782 Jan Bouckaert and Hans Degryse, Softening Competition by Enhancing Entry: An Example from the Banking Industry, October 2002

783 Johann K. Brunner and Susanne Pech, Adverse Selection in the Annuity Market with Sequential and Simultaneous Insurance Demand, October 2002

784 Gregory D. Hess and Eduard Pelz, The Economic Welfare Cost of Conflict: An Empirical Assessment, October 2002

785 Jan Erik Askildsen, Uwe Jirjahn, and Stephen C. Smith, Works Councils and Environmental Investment: Theory and Evidence from German Panel Data, October 2002

786 Geir H. Bjønnes, Dagfinn Rime, and Haakon O. Aa. Solheim, Volume and Volatility in the FX-Market: Does it matter who you are?, October 2002 
787 John Evans and John Fingleton, Entry Regulation and the Influence of an Incumbent Special Interest Group, October 2002

788 Wolfgang Ochel, International Comparisons and Transfer of Labour Market Institutions, October 2002

789 B. Gabriela Mundaca, Moral Hazard Effects of Bailing out under Asymmetric Information, October 2002

790 Gene M. Grossman and Edwin L.-C. Lai, International Protection of Intellectual Property, October 2002

791 John Hassler, José V. Rodriguez Mora, Kjetil Storesletten, and Fabrizio Zilibotti, A Positive Theory of Geographic Mobility and Social Insurance, October 2002

792 Paul De Grauwe and Marianna Grimaldi, The Exchange Rate in a Model with Heterogeneous Agents and Transactions Costs, October 2002

793 Guido Friebel and Mariassunta Giannetti, Fighting for Talent: Risk-shifting, Corporate Volatility, and Organizational Change, October 2002

794 Jan Erik Askildsen, Badi H. Baltagi, and Tor Helge Holmås, Will Increased Wages Reduce Shortage of Nurses? A Panel Data Analysis of Nurses' Labour Supply, October 2002

795 Marko Köthenbürger and Panu Poutvaara, Social Security Reform and Intergenerational Trade: Is there Scope for a Pareto-Improvement?, October 2002

796 Paul De Grauwe and Laura Rinaldi, A Model of the Card Payment System and the Interchange Fee, October 2002

797 Volker Böhm and Tomoo Kikuchi, Dynamics of Endogenous Business Cycles and Exchange Rate Volatility, October 2002

798 Mariam Camarero, Javier Ordóñez, and Cecilio Tamarit, The Euro-Dollar Exchange Rate: Is it Fundamental?, October 2002

799 Misa Tanaka, How Do Bank Capital and Capital Adequacy Regulation Affect the Monetary Transmission Mechanism?, October 2002

800 Jörg Baten and Andrea Wagner, Autarchy, Market Disintegration, and Health: The Mortality and Nutritional Crisis in Nazi Germany, 1933-1937, October 2002

801 Saku Aura, Uncommitted Couples: Some Efficiency and Policy Implications of Marital Bargaining, October 2002

802 Wolfram F. Richter, Delaying Integration of Immigrant Labor for the Purpose of Taxation, October 2002 